\title{
Profitability of biomass production in relation to harvesting technology
}

\author{
Dariusz Kwaśniewski ${ }^{1, *}$, Maciej Kuboń ${ }^{1,2}$, and Urszula Malaga-Toboła ${ }^{1}$ \\ ${ }^{1}$ Department of Production Organization, Logistics and Applied Computer Science, University of \\ Agriculture in Krakow, Poland \\ ${ }^{2}$ Institute of Technical Sciences, State Vocational East European Higher School in Przemyśl, Poland.
}

\begin{abstract}
The aim of the paper was to determine the production costs and profitability of biomass production from Virginia mallow including various harvesting technologies. The paper covered theoretical calculation of the production costs of biomass form Virginia mallow with the use of the computer application "Biocalculator". Calculations were made for a plantation with the surface area of 5 ha and four technologies of harvesting and the product form (pressed straw, chaff). The paper determines the profitability of production of biomass from Virginia mallow for four variants of sale prices of biomass at the level of 100,120,140 and 150 PLN $\cdot t^{-1}$. In case of T1 technology all assumed prices of sale of Virginia mallow biomass with the obtained production costs were profitable. On the other hand, in T3 and T4 technology, the scope of sale prices from 120 to $150 \mathrm{PLN} \cdot \mathrm{t}^{-1}$ caused that the biomass production was profitable. While, the least profitable was application of T2 technology where only at the assessment of biomass sale $150 \mathrm{PLN} \cdot \mathrm{t}^{-1}$ production was profitable and in the remaining price options the profit was not obtained.
\end{abstract}

\section{Introduction}

Biomass is one of renewable energy sources, and energy plants are a type of biomass. The term "energy plants" means annual and perennial cultivars cultivated on agricultural land and processed into biofuels, biocomponents, thermal or electric energy $[1,2]$.

Basic groups of energy plants are:

- Annual plants (grains, rape, maize, sugar cane, sorgo),

- Fast-rotation tree plants (willow, poplar, aspen),

- perennial, fast-growing grass which yields every year (reed-canary grass, miscanthus),

- perennial, fast-growing plants (Virginia mallow, topinambour) [3].

In 2010, perennial energy crops covered a symbolic surface area of ca. 10200 ha, which referred to the general area of agricultural land in the country was approximately $0.05 \%$. The following species prevailed in the crop: bushy willow 6160 ha, poplar 648 ha, birch, and alder 23 ha, giant miscanthus 1833 ha, other perennial grasses 1364 ha, reed-canary grass 53 ha and Virginia mallow 122 ha [4].

\footnotetext{
*Corresponding author: dariusz.kwasniewski@ur.krakow.pl
} 
Virginia fanpetals - Sida hermaphrodita (L.) Rusby is one of almost 200 species which belong to Sida (L.) genus mallow family (Malvaceae). However, some botanists believe that this species should be recognized as a genus due to its considerable differences in comparison to other species. While, molecular phylogenetic studies suggest a relation of Sida to Sidasodes type which occurs in South America [5.6]. Current observations and results of experiments show that in the cultivation for seeds, this perennial plant may be used for 15-20 years. Thanks to setting buds on roots in the pre-stem zone, the plant regrows every year increasing the number of stems from one in the first year to 20-30 in the fourth and following years (in the conditions of a wide distribution of plants), forming quite strongly leaved bush $[7,8]$.

The date of harvesting stems of Virginia mallow for energy purposes is quite extensive and depends on weather conditions, condition of the soil, that influences the use of machines, biomass purpose. Harvesting takes place after a natural end of plants vegetation (October-November) or after fall ground frost. Biomass collected within this time limit has a higher water content. Stems collected in winter are less moist and include more dry mass. A winter harvesting date is sometimes necessary due to the condition of the ground. In case of harvesting of Virginia mallow on the sewage sediment or other area with a similar structure, the use of machines is possible only after its freezing. Even, with a very delayed time limit of harvesting, seeds that weakly earth up do not cause greater losses in their yields [5].

Studies carried out in IUNG-PIB indicate that the size of Virginia mallow yield is mainly influenced by the crop density. At the density of 10 thousand per hectare, regardless the soil quality, the average yield of dry mass of Virginia mallow for four years was ca. 9.5 $\mathrm{t} \cdot$ ha- 1 and in particular years it was from 7.9 to $11.4 \mathrm{t} \cdot \mathrm{ha}-1$. While, at the stock of 20 thousand per hectare, the average yield for four years on the heavy soil was 18.0 and on the light soil - $16.4 \mathrm{t} \cdot \mathrm{ha}-1$ [9].

Virginia mallow may be harvested in one stage, which is characterised with simultaneous cutting and fragmentation with a chaff-cutter or cutting plants with harvesting with a large size press. A multi-stage harvesting may be used on a smaller area, where each stage is performed by separate machines. In the first phase, plants are cut off and in the other, fragmented or pressed when needed. The stages include respectively mowing, pressing, loading material, transport and storing $[5,10]$.

Harvesting may be performed with rotational mowers or field straw-cutters (tractor or mobile). Field straw-cutters, in particular those with Kemper or Krone non-row unit are the most often used nowadays. These plants may be also harvested with maize harvesting combine tractors. Plants cut off with rotational, bottom-drive mowers after being formed into rolls may be collected with rolling presses or large-size pistons. Cutting units of the harvesting machines should be set at the lowest possible height of mowing to avoid losses. Some of the machines by Class and Deutz-Fahr specially adapted for cutting plants and their binding [11].

Cost effectiveness of biomass production for energy purposes depends on the size of yield and its price, area of a field and technology of harvest. Along with the increase of yield, cost per a mass unit decreases. Also, the use of modern machines with a considerable performance working on fields with big acreage enables to considerably limit the costs $[12,13,22]$. Selection and exploitation of the machinery park $[14,15]$ used in the biomass production process is also important.

We may distinguish the following stages in the biomass production processes setting of a plantation, use (running) a plantation) and liquidation of a plantation. The biomass production processes are related with these stages and planning the period of plantation use should be taken into consideration in calculation of costs. The costs of setting and 
liquidation of a plantation referred to the years of its use will enable estimation of the average annual costs of running a plantation $[16,17]$.

Taking into consideration profitability of biomass production we should remember about a crucial factor that includes the costs of biomass production, namely shipping of the ready good (raw material), manner of its loading and unloading (manual, mechanised). The water content of the produced biomass (from ca. $20 \%$ to even $60 \%$ ), its bulk density and distance, to which it will be transported to destination (e.g. a heating plant, farm) $[17,18,23]$.

\section{Objective, scope, and methodology of work}

The aim of the paper was to determine the production costs and profitability of biomass production from Virginia mallow including various harvesting technologies.

The paper covered theoretical calculation of the production costs of biomass form Virginia mallow with the use a computer application "Biocalculator". Calculations were made for four technologies of harvesting and the product form (pressed straw, chaff).

Set technologies of harvesting of Virginia mallow:

- T1 - harvesting with the use of a rotational mower and small press, transport with manual loading and unloading,

- T2 - harvesting with a rotational mower and rolling press, transport with bale gripper,

- T3 - harvesting with a tractor chaff-cutter, continuous reception, transport with the use of two trailers (trailers use interchangeably),

- T4 - harvesting with the use of a mobile field cutter, continuous reception, transport by two trailers (trailers used interchangeably).

The following assumptions were accepted for calculations:

- surface area of Virginia mallow cultivation: 5 ha,

- yield of fresh biomass: $15 \mathrm{t} \cdot \mathrm{ha}^{-1}$,

- period of plantation use: 15 years,

- amount of needed sowing material: $3 \mathrm{~kg} \cdot \mathrm{ha}^{-1}$,

- dose of fertilizers in the amount of a clean component: nitrogen $35 \mathrm{~kg} \cdot \mathrm{ha}^{-1}$, phosphorus $25 \mathrm{~kg} \cdot \mathrm{ha}^{-1}$, potassium $40 \mathrm{~kg} \cdot \mathrm{ha}^{-1}$,

- distance from a farm to a plantation: $3 \mathrm{~km}$.

Costs of setting up the plantation of Virginia mallow ( $\left.\mathrm{K}_{\text {zplant }}\right)$ was determined as a sum of mechanization costs $\left(\mathrm{K}_{\text {mech }}\right)$, material costs $\left(\mathrm{K}_{\mathrm{mat}}\right)$ and remaining costs $\left(\mathrm{K}_{\mathrm{poz}}\right)$ :

$$
\mathrm{K}_{\text {zplant }}=\mathrm{K}_{\mathrm{mech}}+\mathrm{K}_{\mathrm{mat}}+\mathrm{K}_{\mathrm{poz}} \quad(\mathrm{PLN})
$$

Mechanization costs were determined pursuant to the methodology used in the Institute of Agricultural Engineering and Computer Science of the University of Agriculture in Krakow $[16,19]$. They were determined as a sum of fixed costs $\left(K_{\mathrm{st}}\right)$ and variable costs $\left(\mathrm{K}_{\mathrm{zm}}\right)$ and costs of work allocated separately $\left(\mathrm{K}_{\mathrm{pr}}\right)$ :

$$
\mathrm{K}_{\mathrm{mech}}=\mathrm{K}_{\mathrm{st}}+\mathrm{K}_{\mathrm{zm}}+\mathrm{K}_{\mathrm{pr}} \quad(\mathrm{PLN})
$$

Material costs include costs of purchase of sowing material $\left(\mathrm{K}_{\text {siew }}\right)$, costs of purchase of mineral fertilisers $\left(\mathrm{K}_{\text {naw }}\right)$, costs of purchase of crop protection substances $\left(\mathrm{K}_{\text {sor }}\right)$ and costs of water used for spraying $\left(\mathrm{K}_{\mathrm{w}}\right)$ and costs of a rope of pressing $\left(\mathrm{K}_{\mathrm{sz}}\right)$.

$$
\mathrm{K}_{\text {mat }}=\mathrm{K}_{\text {siew }}+\mathrm{K}_{\text {naw }}+\mathrm{K}_{\text {sor }}+\mathrm{K}_{\mathrm{w}}+\mathrm{K}_{\mathrm{sz}} \quad(\mathrm{PLN})
$$


Technical and exploitation parameters of the machinery park used for setting up the plantation of Virginia mallow and indispensable to calculate the mechanization costs were determined based on the data and standards of literature [20,21].

For calculation of exploitation costs of machines and material costs the following assumptions and prices were assumed:

- Virginia mallow - sowing material - $1400 \mathrm{PLN} \cdot \mathrm{kg}^{-1}$,

- diesel oil - 5.20 PLN $\cdot \mathrm{l}^{-1}$,

- water for spraying - 3.80 PLN $\cdot \mathrm{m}^{-3}$,

- ammonium nitrate $28 \% \mathrm{~N}-1.35 \mathrm{PLN} \cdot \mathrm{kg}^{-1}$,

- triple superphosphate $46 \% \mathrm{P}_{2} \mathrm{O}_{5}-1.60 \mathrm{PLN} \cdot \mathrm{kg}^{-1}$,

- potassium salt $60 \% \mathrm{~N}-1.72 \mathrm{PLN} \cdot \mathrm{kg}^{-1}$,

- roundup $360 \mathrm{SL}-30 \mathrm{PLN} \cdot \mathrm{l}^{-1}$,

- rope $-42 \mathrm{PLN} \cdot \mathrm{kg}^{-1}$,

- pay for an operator - 14 PLN'man-hour-1,

- pay for a help - $11 \mathrm{PLN} \cdot \mathrm{man}-$ hour $^{-1}$,

- remaining costs (e.g. analysis of soil, tax for land) - $20 \mathrm{PLN} \cdot \mathrm{ha}^{-1}$.

Costs of production of biomass from Virginia mallow was estimated with the use of computer application "Biocalculator". It was made by employees of the Department of Production Engineering and Power Industry of the University of Agriculture in Krakow as a part of the Research project no. PBZ-MNiSW - 1/3/2006 titled: "Modern technologies of energy use of biomass and biodegradable waste - their conversion to energy gas fuels". One of the co-authors of the program is a thesis supervisor of this paper.

The program is available at the webpage http://biob.wipie.ur.krakow.pl/biobkalk/ [24].

"Biocalculator" is an information system of complex advisory with regard to biomass production and processing as a substitute of a traditional energy carrier used for heating purposes. It has a modular character. It means that four separate modules where separated in the program which the user may use separately or in connection to the remaining ones.

- Module 1: Enables estimation of the energy demand to heat a building (with traditional energy carriers or biomass) and to make an estimated energy audit of the building.

- Module 2: enables estimation of the labour inputs and energy inputs for production of biomass in field crops and costs of production of biomass and energy in biomass.

- Module 3: enables estimation of the labour inputs and energy inputs and costs of compact biofuels production (briquettes or pellets) from biomass.

- Module 4: includes a base of technical devices for production, processing, and combustion of biomass.

Module 2 was used in this paper for calculation of biomass production costs. The biomass production costs were determined as a sum of amortisation costs of a plantation (ratio of costs of setting a plantation and planned period of its use) and biomass harvesting costs in the subsequent year including four technologies of harvesting.

The index of profitability of biomass production [17, 18] from Virginia mallow was determined as:

where:

$$
W_{o p}=\frac{P}{K} \cdot 100
$$

$W_{o p}$ - index of profitability of biomass production (-),

$P$ - value of production of biomass from Virginia mallow (PLN $\left.\cdot y^{-a}{ }^{-1}\right)$,

$K$ - costs of production of biomass from Virginia mallow (PLN·year ${ }^{-1}$ ). 
Four variants of the price of biomass $100,120,140,150 \mathrm{PLN} \cdot \mathrm{t}^{-1}$ were used for calculations of the biomass production value.

\section{Research results}

Table 1 presents an operation sheet of cultivation of Virginia mallow with suggested technological treatments to be performed in the year when the plantation was set including the analysed technologies of harvesting. Based on the calculated performance of work, labour inputs in man-hour were estimated for each treatment. These inputs in the further part of the study enable determination of labour inputs of the total labour in relation to the applied technology of harvesting. The following symbols were assumed for calculation of labour inputs:

- $\mathrm{i}_{\mathrm{os}}$ - number of persons that work on a single unit (persons),

- $\mathrm{W}_{\mathrm{t}}$ - theoretical performance (effective) of a single unit $\left(\mathrm{ha} \cdot \mathrm{h}^{-1}\right)$,

- $\mathrm{W}_{07}$ - exploitation performance of a single unit $\left(\mathrm{ha} \cdot \mathrm{h}^{-1}\right)$,

- $\mathrm{T}_{07}$ - operational time of a single unit (treatment duration) (h).

Table 1. Operation sheet of cultivation of Virginia mallow on the surface area of 5 ha and technology of harvesting

\begin{tabular}{|c|c|c|c|c|c|c|c|c|}
\hline \multirow{2}{*}{$\begin{array}{l}\text { Time } \\
\text { limit }\end{array}$} & \multirow{2}{*}{$\begin{array}{c}\text { Technological } \\
\text { treatment }\end{array}$} & \multicolumn{3}{|c|}{ Unit } & & \multirow{2}{*}{$\mathrm{W}_{07}$} & \multirow{2}{*}{$\mathrm{T}_{07}$} & \multirow{2}{*}{$\begin{array}{l}\text { Labour } \\
\text { inputs }\end{array}$} \\
\hline & & Tractors & Machine & $\mathrm{i}_{\mathrm{os}}$ & & & & \\
\hline dek/m-c & - & Typ & Typ & (osoby) & $\left(\mathrm{ha} \cdot \mathrm{h}^{-1}\right)$ & $\left(\mathrm{ha} \cdot \mathrm{h}^{-1}\right)$ & (h) & (rbh) \\
\hline $3 \mathrm{IX}$ & Spraying & $\begin{array}{l}\text { Pronar } \\
1025 A\end{array}$ & $\begin{array}{l}\text { Heros } \\
800 / 15\end{array}$ & 1 & 10,50 & 5,25 & 1,0 & 1,0 \\
\hline $1 X$ & Winter ploughing & $\begin{array}{l}\text { Pronar } \\
1025 \mathrm{~A}\end{array}$ & $\begin{array}{c}\text { Stanrol } \\
\text { U170 }\end{array}$ & 1 & 0,84 & 0,59 & 8,5 & 8,5 \\
\hline $2 \mathrm{III}$ & Harrowing & $\begin{array}{l}\text { Roller } \\
\text { 70DT }\end{array}$ & $\mathrm{U} 356 / 1$ & 1 & 2,94 & 2,06 & 2,4 & 2,4 \\
\hline 3III & Mineral fertilization & $\begin{array}{l}\text { Roller } \\
\text { 70DT }\end{array}$ & $\begin{array}{c}\text { Motyl } \\
\text { N057/1 }\end{array}$ & 1 & 9,00 & 4,50 & 1,1 & 1,1 \\
\hline 3III & Cultivation with aggregate & $\begin{array}{l}\text { Pronar } \\
1025 \mathrm{~A} \\
\end{array}$ & $\begin{array}{l}\text { Bartmet } \\
\text { U778/9 }\end{array}$ & 1 & 1,40 & 0,98 & 5,1 & 5,1 \\
\hline $1 \mathrm{IV}$ & Mechanical sowing & $\begin{array}{l}\text { Pronar } \\
1025 \mathrm{~A} \\
\end{array}$ & $\begin{array}{c}\text { Lemken } \\
7 / 400-D S\end{array}$ & 1 & 2,40 & 1,44 & 3,5 & 3,5 \\
\hline $3 \mathrm{IV}$ & Mechanical weeding & $\begin{array}{l}\text { Roller } \\
\text { 70DT }\end{array}$ & $\begin{array}{c}\text { Solan } \\
\text { P501/5 }\end{array}$ & 1 & 1,08 & 0,70 & 7,1 & 7,1 \\
\hline $1 \mathrm{~V}$ & Manual weeding & manual & - & 3 & - & 0,1 & 16,7 & 50,0 \\
\hline $2 \mathrm{~V}$ & Mechanical weeding & $\begin{array}{l}\text { Roller } \\
\text { 70DT }\end{array}$ & $\begin{array}{c}\text { Solan } \\
\text { P501/5 }\end{array}$ & 1 & 1,08 & 0,70 & 7,1 & 7,1 \\
\hline \multicolumn{9}{|c|}{ Technology of harvesting T1 } \\
\hline $1 \mathrm{II}$ & Mowing & $\begin{array}{l}\text { Roller } \\
\text { 70DT }\end{array}$ & $\begin{array}{c}\text { Zetor } \\
\text { ZTR } 185 \\
\end{array}$ & 1 & 1,26 & 0,76 & 6,6 & 6,6 \\
\hline $1 \mathrm{II}$ & Pressing & $\begin{array}{r}\text { Pronar } \\
1025 \mathrm{~A} \\
\end{array}$ & $\begin{array}{c}\text { Sipma } \\
\text { Z224 }\end{array}$ & 1 & 0,72 & 0,43 & 11,6 & 11,6 \\
\hline $1 \mathrm{II}$ & Transport & $\begin{array}{l}\text { Roller } \\
\text { 70DT }\end{array}$ & $\begin{array}{l}\text { Pronar } \\
\text { T653/2 } \\
\end{array}$ & 3 & - & - & 15,0 & 45,0 \\
\hline \multicolumn{9}{|c|}{ Technology of harvesting T2 } \\
\hline $1 \mathrm{II}$ & Mowing & $\begin{array}{r}\text { Pronar } \\
1025 \mathrm{~A} \\
\end{array}$ & $\begin{array}{c}\text { Zetor } \\
\text { ZTR } 185\end{array}$ & 1 & 1,26 & 0,76 & 6,6 & 6,6 \\
\hline $1 \mathrm{II}$ & Pressing & $\begin{array}{l}\text { Roller } \\
\text { 70DT }\end{array}$ & $\begin{array}{c}\text { Sipma } \\
\text { Z569/1 }\end{array}$ & 1 & 0,72 & 0,43 & 11,6 & 11,6 \\
\hline
\end{tabular}




\begin{tabular}{|c|c|c|c|c|c|c|c|c|}
\hline 1II & Transport & $\begin{array}{c}\text { Pronar } \\
1025 \mathrm{~A}\end{array}$ & $\begin{array}{c}\text { Warfama } \\
\text { T127 }\end{array}$ & 1 & - & - & 20,0 & 20,0 \\
\hline \multicolumn{7}{|c|}{ Technology of harvesting T3 } \\
\hline 2II & Mowing (chaff-cutter) & $\begin{array}{c}\text { Pronar } \\
\text { 1025A }\end{array}$ & $\begin{array}{c}\text { Sipma } \\
\text { Z364 }\end{array}$ & 1 & 0,35 & 0,21 & 23,8 & 23,8 \\
\hline 2II & Transport & $\begin{array}{c}\text { Roller } \\
70 \mathrm{DT}\end{array}$ & $\begin{array}{c}\text { Pronar } \\
\text { T663/1 (2 szt.) }\end{array}$ & 1 & - & - & 23,8 & 23,8 \\
\hline \multicolumn{7}{|c|}{ Technology of harvesting T4 } \\
\hline 2II & Mowing (chaff-cutter) & - & $\begin{array}{c}\text { Class } \\
\text { Jaguar 870 }\end{array}$ & 1 & 2,66 & 1,60 & 3,1 & 3,1 \\
\hline 2II & Transport & $\begin{array}{c}\text { Pronar } \\
\text { 1025A }\end{array}$ & $\begin{array}{c}\text { Pronar } \\
\text { T663/1 (2 szt.) }\end{array}$ & 1 & - & - & 3,1 & 3,1 \\
\hline
\end{tabular}

An assumption was made in the analysis of labour inputs that Virginia mallow will be cultivated on the wasteland, thus the first treatment in the technological card was spraying and the applied chemical substance was Roundup 360L in the dose of $61 \cdot \mathrm{ha}^{-1}$. Because of the fact that in the year where plantation was set, the fight with weeds plays a key role among technological treatments. Moreover, double mechanical weeding was planned, performed by one person (14.2 man-hour) and single manual weeding performed by 3 persons (50 man-hour).

The set of labour inputs and mechanization costs for setting a plantation of Virginia mallow including four applied technologies of harvesting were placed in table 2.

The biggest inputs of labour which have to be incurred on production of Virginia mallow is generated by $\mathrm{T} 1$ technology (harvesting with the use of a mower and small-sizes press). They are 149 man-hours which calculated per 1 ha give 29.8 man-hour per a tone of the obtained yield 2.0 man-hour. Another technology with regard to the size of labour inputs was T2 technology (harvesting with the use of a mower and rolling press). Inputs were 124.0 man-hour (24.8 man-hour $\left.\cdot h^{-1}\right)$. When T3 technology was used for harvesting (with the use of a tractor chaff-cutter) the total labour was 118.1 man-hour which per 1 ha gives 23.6 man-hour. The highest labour inputs in this technology of harvesting were incurred for manual weeding and mowing since the treatment was performed by a single-row field chaff-cutter Z364. While the lowest labour inputs were characteristic for T4 technology (harvesting with the use of a mobile chaff-cutter) and were 92.0 man-hour (18.4 manhour $\left.\cdot \mathrm{ha}^{-1}\right)$.

Table 2. Labour inputs and mechanization costs for setting a plantation of Virginia mallow and harvesting technology

\begin{tabular}{|c|c|c|c|c|c|}
\hline Specification & \multicolumn{4}{|c|}{ Harvesting technology } & Unit \\
\hline- & T1 & $\mathrm{T} 2$ & T3 & $\mathrm{T} 4$ & - \\
\hline Total labour inputs & 149,0 & 124,0 & 133,4 & 92,0 & rbh \\
\hline \multirow{2}{*}{ Unit labour inputs } & 29,8 & 24,8 & 26,7 & 18,4 & $\operatorname{man}_{1}$ \\
\hline & 2,0 & 1,7 & 1,8 & 1,2 & man-hour $\cdot \mathrm{t}^{-1}$ \\
\hline Total mechanization costs & 8404,8 & 10592,1 & 8628,4 & 10192,1 & PLN \\
\hline \multirow{2}{*}{$\begin{array}{l}\text { Mechanization costs } \\
\text { unit }\end{array}$} & 1681,0 & 2118,4 & 1725,7 & 2038,4 & PLN $\cdot h^{-1}$ \\
\hline & 112,1 & 141,2 & 115,0 & 135,9 & PLN $\cdot \mathrm{t}^{-1}$ \\
\hline
\end{tabular}

Mechanization costs related to setting up the plantation of Virginia mallow at the level of 8404.8 PLN with the use of harvesting technology T1 proved to be the lowest among all assessed technologies of harvesting. Per 1 ha it was PLN 1681. Contrary, the highest costs (PLN 10592.1) were incurred on setting up the plantation with the use of T2 harvesting technology. 
Table 3 presents a list of material expenditures which must be incurred in the year when the plantation was set up. Material consumption was determined for the area of 5 ha and to calculate material costs prices of specified material expenditures were presented. It should be said here that the assumed material inputs without including harvesting technology are identical. While, $\mathrm{T} 1$ and $\mathrm{T} 2$ technologies required the use of a rope for presses and thus differences in material costs have appeared.

In T2 technology material costs were PLN 25964.3 which per 1 ha of the area gives PLN 5192.9. These costs are the highest and result mainly from application of a bigger amount of a rope than in $\mathrm{T} 1$. For realisation of $\mathrm{T} 3$ and $\mathrm{T} 4$ the rope is not required thus the material costs are at a similar level and are PLN 23759.5 (4751.9 PLN $\left.\cdot \mathrm{ha}^{-1}\right)$.

Table 3. Material expenses and costs for setting the plantation of Virginia mallow including harvesting technology

\begin{tabular}{|c|c|c|c|c|c|c|c|}
\hline Specification & Wear and tear & Unit & Price & \multicolumn{4}{|c|}{ Material costs } \\
\hline- & - & - & PLN & $\mathrm{T} 1$ & $\mathrm{~T} 2$ & $\mathrm{~T} 3$ & $\mathrm{~T} 4$ \\
\hline Sowing material & 15,0 & $\mathrm{~kg}$ & 1400,0 & 21000,0 & 21000,0 & 21000,0 & 21000,0 \\
\hline Ammonium nitrate & 625,0 & $\mathrm{~kg}$ & 1,35 & 843,8 & 843,8 & 843,8 & 843,8 \\
\hline Triple superphosphate & 271,7 & $\mathrm{~kg}$ & 1,60 & 434,7 & 434,7 & 434,7 & 434,7 \\
\hline Potasssium salt & 333,3 & $\mathrm{~kg}$ & 1,72 & 573,3 & 573,3 & 573,3 & 573,3 \\
\hline Roundup 360 SL & 30,0 & 1 & 30,0 & 900,0 & 900,0 & 900,0 & 900,0 \\
\hline Water & 2,0 & $\mathrm{~m}^{3}$ & 3,80 & 7,6 & 7,6 & 7,6 & 7,6 \\
\hline Rope (technology 1) & & & & 787,5 & & & \\
\hline Rope (technology II) & & & & & 2205,0 & & \\
\hline \multicolumn{4}{|l|}{ Total material costs } & & & & 23759,5 \\
\hline \multicolumn{4}{|c|}{ Unit material costs per 1 ha $\left(\mathrm{PLN} \cdot \mathrm{ha}^{-1}\right)$} & & & & 4751,9 \\
\hline \multicolumn{4}{|c|}{ Unit material costs per 1 tone $\left(\mathrm{PLN} \cdot \mathrm{ha}^{-1}\right)$} & & & & 316,8 \\
\hline
\end{tabular}

Costs of setting the plantation are a sum of mechanization costs, material costs and remaining costs such as e.g. land tax and soil analysis. Table 4 presents the costs of setting the plantation of Virginia mallow including the harvesting costs in relation to the harvesting technology.

It should be emphasised that the unit costs of setting the plantation are the highest for T2 technology and are 7331.3 PLN $\cdot \mathrm{ha}^{-1}$ and participation of costs in this case is $17.2 \%$. Whereas the lowest are characteristic for T3 technology i.e. 6497.6 PLN.ha-1 ${ }^{-1}$ including harvesting costs $13.4 \%$.

Table 4. Costs of setting the plantation of Virginia mallow in relation to harvesting technology

\begin{tabular}{|c|c|c|c|c|c|}
\hline & \multicolumn{5}{|c|}{ Harvesting technology } \\
\hline Specification & \multicolumn{5}{|c|}{ Unit } \\
\hline & T1 & T2 & T3 & T4 & Unit \\
\hline Mechanization costs & 8404,8 & 10592,1 & 8628,4 & 10192,1 & PLN \\
\hline
\end{tabular}




\begin{tabular}{|c|c|c|c|c|c|}
\hline Material costs & 24546,8 & 25964,3 & 23759,5 & 23759,5 & PLN \\
\hline Remaining costs & 100,0 & 100,0 & 100,0 & 100,0 & PLN \\
\hline Total costs of setting the plantation & 33051,6 & 36656,5 & 32487,9 & 34051,6 & PLN \\
\hline Including harvesting & 4124,5 & 6311,9 & 4381,1 & 5958,5 & PLN \\
\hline Total costs of setting the plantation & 6610,3 & 7331,3 & 6497,6 & 6810,3 & PLN.ha ${ }^{-1}$ \\
\hline Including harvesting & 824,9 & 1262,4 & 876,2 & 1191,7 & PLN.ha- $^{-1}$ \\
\hline
\end{tabular}

To execute the objective of the paper and calculate the biomass production, table 5 shows biomass production costs from Virginia mallow in relation to the harvesting technology and costs of plantation amortisation. Taking into consideration the fact that the planned use of plantation is 15 years, the biomass production costs were within the range from 1423.1 PLN $\cdot h^{-1} \cdot$ year $^{-1}$ for technology T1 do 2192.1 PLN $\cdot h^{-1} \cdot$ year $^{-1}$ for T2. On the other hand, per a ton of the collected biomass it was from 94.8 to $146.1 \mathrm{PLN} \cdot \mathrm{t}^{-1}$. Contrary, amortisation of the plantation in these cases was respectively: 440.7 and $488.8 \mathrm{PLN} \cdot \mathrm{ha}^{-1} \cdot$ year $^{-1}$.

Table 5. Production costs of biomass from Virginia mallow in relation to harvesting technology

\begin{tabular}{|c|c|c|c|c|c|}
\hline \multirow{2}{*}{ Specification } & \multicolumn{4}{|c|}{ Harvesting technology } & \multirow{2}{*}{ Unit } \\
\hline & $\mathrm{T} 1$ & $\mathrm{~T} 2$ & $\mathrm{~T} 3$ & $\mathrm{~T} 4$ & \\
\hline $\begin{array}{c}\text { Amortisation of } \\
\text { plantation }\end{array}$ & 440,7 & 488,8 & 433,2 & 454,0 & PLN $\cdot h^{-1} \cdot$ rok $^{-1}$ \\
\hline \multirow{2}{*}{ Production costs } & 1423,1 & 2192,1 & 1549,2 & 1645,7 & PLN $\cdot h^{-1} \cdot$ rok $^{-1}$ \\
\hline & 94,8 & 146,1 & 103,2 & 109,7 & PLN $\cdot \mathrm{t}^{-1}$ \\
\hline
\end{tabular}

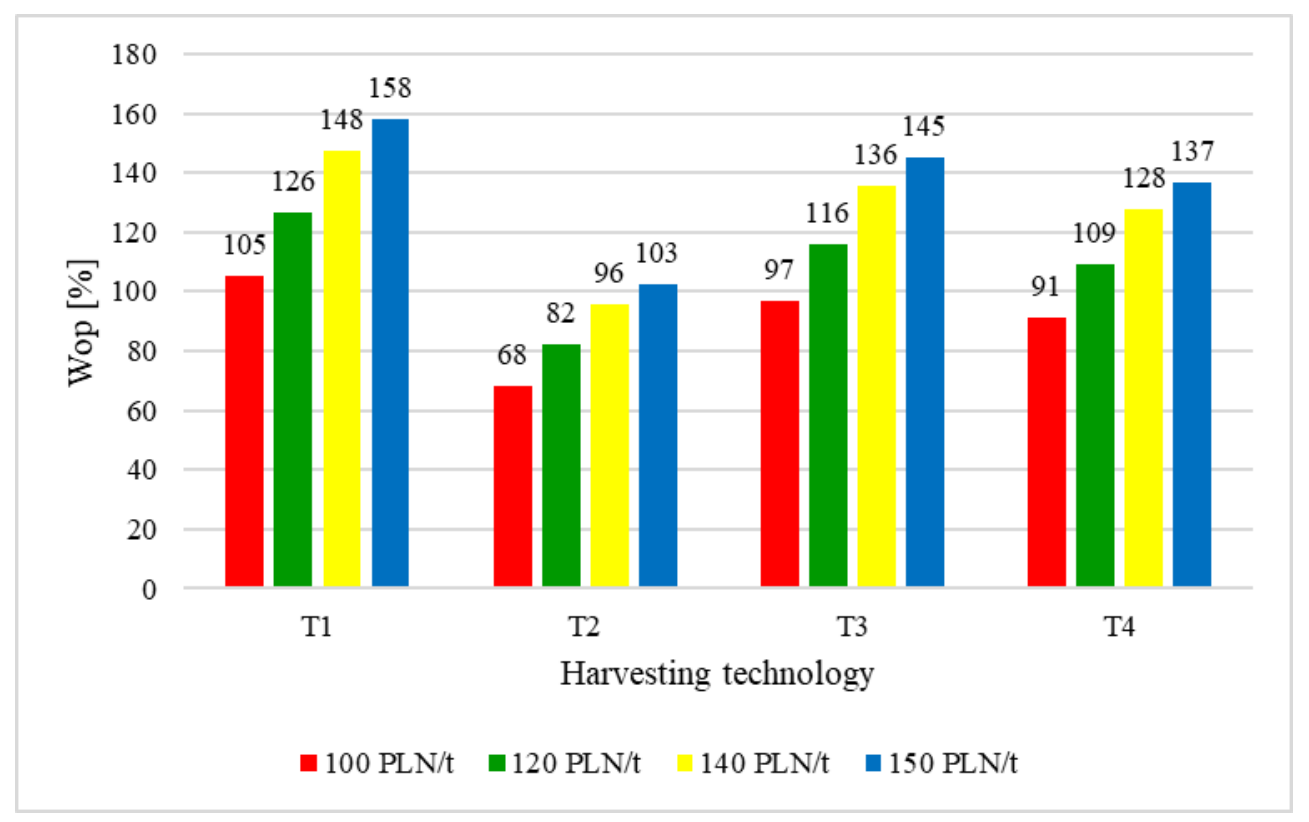

Figure 1. Profitability of biomass production from Virginia mallow in relation to harvesting technology 
While for T2 technology (harvesting with the use of a mower, rolling press and bale gripper) only for prices of sale $150 \mathrm{PLN} \cdot \mathrm{t}^{-1}$ biomass is profitable. On the other hand, for T 3 technology (harvesting with a tractor chaff-cutter) and T4 (harvesting with the use of a mobile chaff-cutter) the most profitable is production for sale prices from 120 to $150 \mathrm{PLN} \cdot \mathrm{t}^{-}$ 1.

\section{Conslusions}

1) Costs of setting the plantation of Virginia mallow with the use of $\mathrm{T} 1$ technology were 6610.3 PLN $\cdot \mathrm{ha}^{-1}$, and the production costs 1423.1 PLN $\cdot \mathrm{ha}^{-1} \cdot \mathrm{year}^{-1}\left(94.87 \mathrm{PLN} \cdot \mathrm{t}^{-1}\right)$. On the other hand, the costs of setting the plantation for T2 technology were at the level of $7331.3 \mathrm{PLN} \cdot \mathrm{ha}^{-1}$ and proved to be the highest among all assessed technologies of harvesting. The production costs of biomass were $2192.1 \mathrm{PLN} \cdot \mathrm{ha}^{-1} \cdot \mathrm{year}^{-1}$, and the costs for one ton 146.1 PLN $\cdot \mathrm{t}^{-1}$. In this case the sale price of biomass would have to be $150 \mathrm{PLN} \cdot \mathrm{t}^{-1}$ to make the production profitable.

2) The costs of setting the plantation with the use of harvesting technology T3 are 6497.6 $\mathrm{PLN} \cdot \mathrm{ha}^{-1}$. These were the lowest costs among all assessed and set technologies of harvesting. While the costs of biomass production were $1549.2 \mathrm{PLN} \cdot \mathrm{ha}^{-1} \cdot \mathrm{year}^{-1}$, per one ton 103.2 PLN $\cdot \mathrm{t}^{-1}$. While the T4 technology generated costs of setting the plantation at the level of $6810.3 \mathrm{PLN} \cdot \mathrm{ha}^{-1}$, and the production costs were 1645.7 $\mathrm{PLN} \cdot \mathrm{ha}^{-1} \cdot \mathrm{year}^{-1}\left(109.7 \mathrm{PLN} \cdot \mathrm{t}^{-1}\right)$.

3) The paper determines profitability of biomass production from Virginia mallow for four variants of biomass sale prices $100,120,140$ and $150 \mathrm{PLN} \cdot \mathrm{t}^{-1}$. In case of T1 technology (mowing and pressing by a small press) all set processes of sale of Virginia mallow biomass at the obtained production costs were profitable, but the highest index of profitability was characteristic for the highest price of biomass.

4) In T3 technologies (harvesting with the use of a tractor chaff-cutter) and T4 (harvesting with the use of a mobile chaff-cutter) only the scope of sale prices from 120 to $150 \mathrm{PLN} \cdot \mathrm{t}^{-1}$ caused that the biomass production was profitable. While, the least profitable option was application of $\mathrm{T} 2$ technology (mowing, pressing with a rolling press and bale gripper where only at the price of biomass sale $150 \mathrm{PLN} \cdot \mathrm{t}^{-1}$ production was profitable and in the remaining price options, profit was not obtained.

\section{References}

1. M. Kołodziej, M. Matyka (red.) Odnawialne źródła energii. Rolnicze surowce energetyczne. Wyd. Powszechne Wydawnictwo Rolnicze i Leśne. Poznań. ISBN 97883-09-01139-2. (2012).

2. R.S. Pacaldo, T.A. Volk, R. Briggs, Greenhouse Gas Potentials of Shrub Willow Biomass Crops Based on Below- and Aboveground Biomass Inventory Along a 19Year Chronosequence. Bioenergy Research 6, 252-262. (2012).

3. A. Kacprzak, K. Michalska, Z. Romanowska-Duda, M. Grzesik, Rośliny energetyczne jako cenny surowiec do produkcji biogazu. Kosmos Problemy Nauk Biologicznych. Polskie Towarzystwo im. Kopernika, Vol. 61, s.282. (2012).

4. S. Szczukowski, J. Tworkowski, M. Stolarski, J. Kwiatkowski, M. Krzyżaniak, W. Lejszner, Ł. Graban, Wieloletnie rośliny energetyczne. Monografia. Multico Oficyna Wydawnicza sp. z o.o. ISBN: 978-837763-051-8. (2012).

5. B. Kościk (red.), H. Borkowska, J. Dubas, P. Gradziuk, A. Kowalczyk-Juśko, W. Martyn, B. Rawicki, B. Styk, T. Węgorek, Rośliny energetyczne. Wyd. AR Lublin. ISBN 83-7259-091-5. (2003). 
6. P. Gradziuk, A. Grzybek, K. Kowalczyk, B. Kościk, Biopaliwa. Wyd. Wieś Jutra. Warszawa. ISBN 83-88-368-10-9. (2003).

7. H. Borkowska, B. Styk, Ślazowiec pensylwański (Sida hermaphrodita Rusby). Uprawa i wykorzystanie. Wyd. AR. Lublin. (1997).

8. H. Borkowska, B. Styk, Ślazowiec pensylwański (Sida hermaphrodita Rusby). Uprawa i wykorzystanie. Wyd. Akademii Rolniczej w Lublinie. Lublin. ISBN 83-7259-142-3. (2006).

9. J. Kuś, M. Matyka, Uprawa roślin na cele energetyczne. Instrukcja upowszechnieniowa nr 179. IUNG-PIB. Puławy. (2010).

10. S. Szczukowski, J. Tworkowski, J. Kuś, M. Stolarski, Produkcyjność roślin uprawianych na cele energetyczne. [w]: Nowoczesne technologie pozyskiwania $i$ energetycznego wykorzystania biomasy. Bocian, Golec, Rakowski (red.). Instytut Energetyki. Warszawa. 34-49. (2010).

11. A. Lisowski (red.), Technologie zbioru roślin energetycznych. Wyd. SGGW. Warszawa. ISBN 978-83-7583-222-8. (2010).

12. K. Ericsson, H. Rosenqvist, E. Ganko, M. Pisarek, L. Nilsson, An agro-economic analysis of willow cultivation in Poland. Biomass and Bioenergy 30(5), 16-27. (2006).

13. M. Stolarski, J. Tworkowski, S. Szczukowski, J. Kwiatkowski, Ł. Graban, Opłacalność i efektywność energetyczna produkcji biomasy ślazowca pensylwańskiego w zależności od stosowanego materiału siewnego. Fragmenta Agronomica 31(2). s. 96-106. (2014).

14. M. Cupial, A. Szelag-Sikora, M. Niemiec, Optimisation of the machinery park with the use of OTR-7 software in context of sustainable agriculture, In: Huyghebaert, B., Lorencowicz, E. and Uziak, J. (eds), Farm Machinery and Processes Management in Sustainable Agriculture 64-69. (2015).

15. Z. Kowalczyk, M. Cupial, Estimation methods of the agricultural equipment value with regard to evaluation of Alina carrot harvester. Contemporary Research Trends in Agricultural Engineering BIO Web Conf., 10 01011. https://doi.org/10.1051/bioconf/ 20181001011. (2018).

16. D. Kwaśniewski, Koszty produkcji biomasy z upraw polowych. W: Frączek J. (red.) Produkcja biomasy na cele energetyczne. Wyd. DRUKROL S.C., Kraków, ISBN 97883-917053-8-4. (2010).

17. D. Kwaśniewski, Koszty i opłacalność produkcji biomasy z trzyletniej wierzby energetycznej. Inżynieria Rolnicza 1(126) Kraków. s. 145-154. (2011).

18. M. Matyka, Opłacalność i konkurencyjność produkcji wybranych roślin energetycznych. Studia i raporty IUNG-PIB. Zeszyt 11. Wyd. Dział Upowszechniania i Wydawnictw IUNG-PIB w Puławach. (2008).

19. J. Kowalski, R. Michałek, M. Kuboń, D. Kwaśniewski, U. Malaga-Toboła, S. Tabor, Uwarunkowania techniczno-ekonomiczne produkcji ekologicznej $w$ gospodarstwach Polski potudniowej. ISBN 978-83-64377-07-5. (2014).

20. A. Muzalewski, Koszty eksploatacji maszyn. Wyd. IBMER Warszawa. ISBN 987-83806-31-4. (2009).

21. E. Lorencowicz, Poradnik uzytkowania techniki rolniczej $w$ tabelach. Agencja Promocji Rolnictwa i Agrobiznesu. Bydgoszcz. ISBN 83-91453-7-8. (2007).

22. M. Kubon, S. Kocira, A. Kocira, D. Leszczynska, Use of Straw as Energy Source in View of Organic Matter Balance in Family Farms. RENEWABLE ENERGY SOURCES: ENGINEERING, TECHNOLOGY, INNOVATION. Springer Proceedings in Energy. pp. 541-547. DOI:10.1007/978-3-319-72371-6_53.

23. M. Kubon, J. Sikora, E. Olech, A. Szelag-Sikora, Energy Islands as a Potential Source of Securing the Energy Supply of Bio-Feedstock for Biogas Plants. RENEWABLE 
ENERGY SOURCES: ENGINEERING, TECHNOLOGY, INNOVATION. Springer Proceedings in Energy. pp. 713-723. DOI: 10.1007/978-3-319-72371-6_70.

24. Biobkalkulator [online]. Dostęp: http://biob.wipie.ur.krakow.pl/biobkalk 